Original article

VERSITA

DOI: $10.2478 / \mathrm{rrlm}-2013-0011$

\title{
Assessment of beta cell function in subjects with newly diagnosed type 2 diabetes
}

\author{
Evaluarea funcției beta celulare la subiecții cu \\ diabet zaharat nou diagnosticat
}

\author{
Simona Cernea ${ }^{*}$, Adina Huțanu ${ }^{2}$, Ligia Coroş², Minodora Dobreanu ${ }^{2,3}$ \\ 1. Diabetes, Nutrition and Metabolic Diseases Outpatient Unit, Emergency County Clinical Hospital, \\ Târgu Mureş, Romania \\ 2. Clinical Laboratory Department, Emergency County Clinical Hospital, Târgu Mureş, Romania \\ 3. Department of Clinical Biochemistry, University of Medicine and Pharmacy, Târgu Mureş, Romania
}

\begin{abstract}
Objectives: The primary aim of this study was to assess residual beta cell function at diagnosis of type 2 diabetes and identify accessible laboratory markers that best estimate it. The secondary objective was to evaluate the change in beta cell function 6 months after starting different therapeutical regimens. Materials and methods: Forty seven subjects were included in the study and each performed a 75-g oral glucose tolerance test (OGTT) at baseline and after 6 months. Metabolic and immunologic parameters were determined from fasting samples. According to the degree of metabolic decompensation, specific therapy was started: metformin, metformin plus gliclazide or insulin therapy (with/out metformin). Early and total beta cell function was evaluated by the disposition index (DI) calculated for 30 minutes and 120 minutes, respectively. Results: At diagnosis, fasting blood glucose (BG) and HbAlc varied largely $(129-521 \mathrm{mg} / \mathrm{dl}$ and $5.5-14 \%$, respectively). The DI30 and DII20 decreased with more severe glycemic decompensation. For both DI30 and DI120 significant negative correlations were found for glycemic markers (HbAlc, 2-hour BG and maximal BG amplitude) and positive correlation for 2hour C peptide ( $p<0.0001$ for all). HbAlc value of $7 \%$ discriminated an important decrease of DI30 and DII20. Insulin and combined therapy significantly improved DI120 at 6 months ( $p: 0.0062$ and 0.01, respectively), while DI30 was improved only with insulin therapy ( $p$ : 0.0326). Conclusions: Beta cell function at onset correlated with HbAlc, 2-hour BG and C peptide during OGTT. Thus OGTT and HbAlc are pivotal for evaluation of beta cell function. Insulin therapy improved early and total insulin secretion at 6 months.
\end{abstract}

Keywords: type 2 diabetes; beta cell function; biological markers; insulin therapy

\section{Rezumat}

Obiective: Scopul principal al acestui studiu a fost evaluarea funcției beta celulare reziduale la diagnosticul diabetului zaharat tip 2 şi identificarea unor markeri de laborator cu ajutorul cărora să se efectueze o

*Corresponding author: Simona Cernea, Diabetes, Nutrition and Metabolic Diseases Outpatient Unit Emergency County Clinical Hospital, 50 Gheorghe Marinescu str.; rm. 4080, Târgu Mureş, Romania. Tel: 0265-212111/368, Email: simonacernea@yahoo.com 
cât mai bună estimare a acesteia. Obiectivul secundar a fost evaluarea modificării funcției beta celulare cu diferite regimuri terapeutice. Materiale şi metode: Patruzeci şi şapte subiecți au fost incluşi în studiu şi fiecare a efectuat un test de toleranță la glucoză oral (TTGO) cu $75 \mathrm{~g}$ glucoză la înrolare şi la 6 luni. Parametri metabolici şi imunologici au fost determinați din probe à jeun. În funcție de gradul decompensării metabolice, terapia specifică a fost inițiată: metformin, metformin plus gliclazid sau insulinoterapia (cu/fără metformin). Funcția beta celulară inițială şi totală a fost evaluată cu ajutorul disposition index (DI) calculat pentru primele 30 de minute şi respectiv 120 minute. Rezultate: La diagnostic, glicemia à jeun şi HbAlc au variat în limite largi (129$521 \mathrm{mg} / \mathrm{dl}$ şi respectiv 5.5-14\%). Indicii DI30 şi DI120 au scăzut pe măsura severității decompensării glicemice. Atât pentru DI30, cât şi pentru DI120 s-au depistat corelații negative semnificative cu markerii glicemici (HbAlc, glicemia la 2 ore şi amplitudinea maximă a glicemiei) şi corelații pozitive cu peptidul C la 2 ore ( $p<0.0001$ pentru toți). Valoarea HbAlc de $7 \%$ a diferențiat o scădere importantă a DI30 şi DI120. Insulinoterapia şi terapia combinată a imbunătățit semnificativ DI120 la 6 luni (p: 0.0062 şi respectiv 0.01), în timp ce DI30 a crescut numai sub terapia cu insulină (p: 0.0326). Concluzii: Funcția beta celulară la debut a fost corelată cu HbAlc, glicemia şi peptidul C la 2 ore în timpul TTGO. De aceea, TTGO şi HbAlc sunt esențiale pentru evaluarea funcției beta celulare. Insulinoterapia a îmbunătățit secreția inițială şi totală endogenă de insulină la 6 luni.

Cuvinte-cheie: diabet zaharat tip 2; funcția beta celulară; markeri biologici; insulinoterapie

Received: 30 $0^{\text {th }}$ April 2013; Accepted: $1^{\text {st }}$ June 2013; Published: $15^{\text {th }}$ June 2013.

\section{Introduction}

Beta cell dysfunction and insulin resistance are the core pathophysiologic defects in type 2 diabetes, and in fact hyperglycemia ensues when insulin secretion is not adequate for a certain degree of insulin resistance. The progression of the disease is thought to be mainly due to declining pancreatic beta cell function, so its evaluation has become increasingly important. Recent studies indicate that the decrease of insulin secretion capacity occurs well before the onset of the disease, even in the normal glucose tolerance range $(1,2)$. Thus it has become apparent that the deterioration of beta cell function and mass is a continuum, with no thresholds, and many factors influence it in a positive or negative way (3).

The assessment of beta cell functional capacity may be a valuable tool for better characterization of subjects with diabetes who present various phenotypic features and for a better understanding of the underlying pathophysiologic disorders (4). In addition, it may also guide treatment choice, as available glucose-lowering drugs impact beta cell function and survival differently and new therapeutic agents with a potential to protect/improve beta cell function and mass are being developed (4).
The gold standard method for the measurement of insulin secretion is hyperglycemic clamp, but it bears many inconveniences (high cost, complicated technique requiring time and trained personnel), which makes it unsuitable for large studies and clinical practice (5). Therefore, simpler methods (such as oral glucose tolerance test (OGTT)) are used instead and surrogate measures derived from basal measurements and OGTT have been developed. They seem to correlate well with estimations obtained in clamp studies and with pancreatic beta cell mass $(6,7)$.

The primary aim of this study was to assess beta cell function at diagnosis of type 2 diabetes by means of OGTT and identify laboratory markers that best correlate with it. The secondary objective was to evaluate the change of beta cell function with different therapeutical regimens.

\section{Materials and methods}

Adult subjects with newly diagnosed type 2 diabetes were recruited from the Diabetes Outpatient Unit of the Emergency County Clinical Hospital Târgu Mureş. The study was approved by the Ethics Committees of the Emergency County Clinical Hospital and of the University of Medicine and Pharmacy Târgu 
Mureş and all subjects signed an informed consent before taking part in the study.

Diabetes was diagnosed according to the American Diabetes Association (ADA) criteria (8). Medical history was obtained and a physical examination, which included anthropometrical measurements, was done. Subjects were otherwise in good apparent health and individuals with type 1 diabetes, gestational diabetes or with severe diseases were excluded. Each participant was studied twice - at baseline and after 6 months. At baseline, during the first 10 days after diagnosis, blood was drawn in fasting conditions and an OGTT with $75 \mathrm{~g}$ glucose was performed.

During the first visit at the clinic, when diabetes was diagnosed, each subject received specific education with individualized recommendations for dietary changes and healthy lifestyle, and diabetes specific therapy was started. If at diagnosis fasting blood glucose was < $200 \mathrm{mg} / \mathrm{dl}$, monotherapy with metformin was started (Group 1), for blood glucose over 200 $\mathrm{mg} / \mathrm{dl}$ and/or HbAlc $>8.5 \%$ combination therapy was prescribed (metformin plus gliclazide) (Group 2) and if blood glucose $>250 \mathrm{mg} / \mathrm{dl}$ and/or $\mathrm{HbA1c}>10 \%$ insulin therapy was initiated (associated with metformin for overweight/obese subjects) (Group 3). Patients with fasting blood glucose $>250 \mathrm{mg} / \mathrm{dl}$, that despite recommendations strongly refused insulin therapy were allowed to start combination therapy and were followed up more closely (as were those treated with insulin). The patients basically followed their regular visits at the center and maintained their usual routine. Those with high blood glucose at diagnosis which started insulin or combined therapy were followed up at 1 month and then at 3months intervals at the clinic, while those only on metformin were followed up every 3 months. Subjects that started insulin therapy maintained telephone contact with their treating physician every 3-6 days for the first month in order to adjust insulin doses and normalize blood glucose.

Oral glucose tolerance test (OGTT). Subjects were instructed to fast for at least 10 hours overnight and to refrain from food, drinks, smoking or physical exercise on the morning of the study. Diabetes medication was allowed the day before the study. Long acting insulin was taken the evening before the test, but in the morning no insulin or medication was taken. During the first 2 weeks therapy was adjusted in order to decrease fasting blood glucose to levels $<200 \mathrm{mg} / \mathrm{dl}$, so that the OGTT could be performed. In order to decrease the impact of diurnal variation, the tests started between 8.00 and 9.00 a.m. After the insertion of a small catheter in the antecubital vein and before the basal samples were collected, patients were allowed to rest for about 10 minutes, in order to relax and get accommodated with the conditions of the test. A standard OGTT with $75 \mathrm{~g}$ glucose was performed. Samples were collected at -10, 0, 30, 60, 90 and 120 minutes and immediately centrifuged. Plasma was stored at $-80{ }^{\circ} \mathrm{C}$ for subsequent assays.

Analytical techniques. C-peptide levels were determined by chemiluminiscent immunometric assay technique (Immulite ${ }^{\circledR}$, Underwritters laboratories Inc.). The functional sensitivity of the assay was $0.09 \mathrm{ng} / \mathrm{ml}$, the within-run coefficient of variation $(\mathrm{CV})$ was $3.3 \%$ and total CV $5.5 \%$. Proinsulin, TNF- $\alpha$, IL- 6 , antiGAD and antiIA2 antibodies were determined by an enzyme-linked immunosorbent assay (ELISA MiniBos, Biomedica). For proinsulin the analytical sensitivity was $<0.5 \mathrm{pmol} / \mathrm{l}$ and the intra-assay and inter-assay CVs were $7.4 \%$ and $6.8 \%$, respectively. For TNF- $\alpha$ the sensitivity was $5.0 \mathrm{pg} / \mathrm{ml}$, and the intra-assay and inter-assay CVs were $7.7 \%$ and $8.1 \%$, respectively, while for IL-6 the sensitivity of the assay was $0.92 \mathrm{pg} / \mathrm{ml}$ and the intra-assay and inter-assay CVs were $3.4 \%$ and $5.2 \%$, respectively. For IA-2 ELISA kit the lower detection at +2 SDs was $0.3 \mathrm{U} / \mathrm{ml}$, with inter-assay $\mathrm{CV}$ of $6.6 \%$ and intra-assay of CV 5.1\%. The accuracy of the GAD ELISA test was $85.5 \%$, with inter-assay CV of 5.4\% and intra-assay of CV $4.6 \%$.

Blood glucose during the tests was determined by glucoseoxidase method and a mean of two measurements was calculated. HbAlc was measured from capillary whole blood by means of a 
Table 1. Demographic characteristics, metabolic and immunologic parameters at diagnosis

\begin{tabular}{|c|c|}
\hline \multicolumn{2}{|l|}{ Baseline characteristics } \\
\hline Gender (F/M) & $23 / 24$ \\
\hline Age at diagnosis (yr) & $55.8 \pm 9.7$ \\
\hline M & $52.8 \pm 9.7$ \\
\hline $\mathrm{F}$ & $58.9 \pm 8.9$ \\
\hline Family history diabetes/HT/CVD (no) & $18 / 34 / 30$ \\
\hline Personal history of HT/CVD (no) & $37 / 18$ \\
\hline Smoking & \\
\hline Yes/Ex-smoker/No (no) & $16 / 15 / 16$ \\
\hline Physical exercise & \\
\hline Sedentary/Moderate/Intense (no) & $16 / 29 / 2$ \\
\hline Presence of symptoms (no) & 16 \\
\hline Duration of symptoms (mo) & $5.5 \pm 2.1$ \\
\hline $\mathrm{SBP}(\mathrm{mmHg})$ & $143.1 \pm 25.7$ \\
\hline $\mathrm{DBP}(\mathrm{mmHg})$ & $88.8 \pm 12.5$ \\
\hline $\operatorname{BMI}\left(\mathrm{kg} / \mathrm{m}^{2}\right)$ & $29.85 \pm 4.0$ \\
\hline $\mathrm{F}$ & $29.2 \pm 3.9$ \\
\hline M & $30.7 \pm 4.2$ \\
\hline Waist $(\mathrm{cm})$ & $103.6 \pm 11.0$ \\
\hline $\mathrm{F}$ & $102.3 \pm 9.6$ \\
\hline M & $104.0 \pm 12.7$ \\
\hline Blood glucose at diagnosis $(\mathrm{mg} / \mathrm{dl})$ & $250.9 \pm 102.7$ \\
\hline A1c at diagnosis $(\%)$ & $9.2 \pm 2.4$ \\
\hline Blood ketones at diagnosis (no) & 24 \\
\hline Total cholesterol (mg/dl) & $183.9 \pm 50.1$ \\
\hline HDL cholesterol (mg/dl) & $38.5 \pm 10.8$ \\
\hline LDL cholesterol (mg/dl) & $113.5 \pm 33.7$ \\
\hline Triglycerides $(\mathrm{mg} / \mathrm{dl})$ & $159.8 \pm 137.4$ \\
\hline Fasting C peptide (ng/ml) & $2.5 \pm 1.4$ \\
\hline Fasting proinsulin (pmol/l) & $5.6 \pm 4.5$ \\
\hline $\mathrm{TNF}-\alpha(\mathrm{pg} / \mathrm{ml})$ & $7.6 \pm 9.2$ \\
\hline IL-6 (pg/ml) & $1.0 \pm 1.3$ \\
\hline AntiGAD/ AntiIA2 ab (no) & $10 / 1$ \\
\hline
\end{tabular}

Data are means \pm SD

Clover A1c analyzer (Infopia Co., Ltd). Lipid parameters (total cholesterol, HDL cholesterol, LDL cholesterol and triglycerides) were determined on a Cobas c501 analyzer (Roche Diagnostics).

Calculations. We decided to use $\mathrm{C}$ peptide for estimation of endogenous insulin secretion since it is co-secreted in equimolar amounts with insulin, does not undergo significant hepatic extraction and has a relatively constant kinetics, thus reflecting more accurately the pancreatic insulin production and because some of the subjects were treated with insulin (9). The incremental areas under the curve (AUC) for glucose and $\mathrm{C}$ peptide during the OGTT were calculated using the trapeziodal rule.

Many different indices of beta cell function and insulin sensitivity have been proposed. Insulin response to changes in glucose, or insulinogenic index (incremental AUC of C peptide/incremental AUC of glucose) was calculated for the first 30 minutes and for the entire 120 minute-period, as an estimate of early and total insulin secretion, respectively. A correct quantification of beta cell function however, requires a simultaneous assessment of insulin sensitivity and therefore we evaluated the disposition index (insulin secretion/insulin resistance) (10). We have chosen to evaluate the insulin sensitivity using the HOMA calculator v2.2, because it allows calculations based on $\mathrm{C}$ peptide values. We have also used the HOMA calculator v2.2 to estimate the HOMA B\% from fasting samples.

The main endpoint of the study was the $\beta$ cell function and in order to detect an association between $\beta$ cell function and previously mentioned parameters with a coefficient of corelation of 0.35 , a power of $80 \%$ and a significance level of $\alpha=0.05,49$ subjects needed to be enrolled.

Statistical analysis. Data analysis was done using descriptive and inferential statistics. We have used the Grubbs test to identify outliers and Kolmogorov-Smirnov test to check if the data has a Gaussian distribution. The paired and unpaired $t$ tests were employed for normally distributed data and nonparametric tests (Mann-Whitney and Wilcoxon) for non-gaussian distributed data in order to compare central tendencies of the groups. Pearson and Spearman tests were used to evaluate correlations (associations) between normally and non-normally distributed variables, respectively. The differences between the three 
Table 2. Indices of early and total insulin secretion at baseline

\begin{tabular}{|c|c|c|c|c|c|}
\hline \multirow[b]{2}{*}{ Index } & \multicolumn{5}{|c|}{ Median (range) } \\
\hline & Total group & $\begin{array}{c}\text { Group 1 } \\
\text { (Metformin) } \\
(\mathrm{n}=18) \\
\end{array}$ & $\begin{array}{c}\text { Group 2 } \\
\begin{array}{c}\text { (SU+Metformin) } \\
(\mathrm{n}=13)\end{array} \\
\end{array}$ & $\begin{array}{c}\text { Group 3 } \\
\text { (Insulin } \pm \text { Metformin) } \\
(\mathrm{n}=16)\end{array}$ & $\begin{array}{c}\mathbf{P} \\
\text { (all groups) }\end{array}$ \\
\hline $\begin{array}{l}\text { Insulinogenic } \\
\text { index30 }\end{array}$ & $\begin{array}{c}0.0174 \\
(0.0002-0.1913)\end{array}$ & $\begin{array}{c}0.0314^{\#} \\
(0.0076-0.1913)\end{array}$ & $\begin{array}{c}0.0179 \\
(0.0041-0.0372)\end{array}$ & $\begin{array}{c}0.0077 \\
(0.0002-0.0237)\end{array}$ & $<0.0001$ \\
\hline $\begin{array}{l}\text { Disposition } \\
\text { index30 }\end{array}$ & $\begin{array}{c}0.0085 \\
(0.0004-0.0416)\end{array}$ & $\begin{array}{c}0.0138^{\circ} \\
(0.0038-0.0416)\end{array}$ & $\begin{array}{c}0.0064 \\
(0.0016-0.0291)\end{array}$ & $\begin{array}{c}0.0066 \\
(0.0004-0.0230)\end{array}$ & 0.006 \\
\hline $\begin{array}{l}\text { Insulinogenic } \\
\text { index } 120\end{array}$ & $\begin{array}{c}0.0282 \\
(0.0017-0.1670)\end{array}$ & $\begin{array}{c}0.0710^{* \#} \\
(0.0124-0.1670)\end{array}$ & $\begin{array}{c}0.0285 \\
(0.0017-0.0687)\end{array}$ & $\begin{array}{c}0.0129 \\
(0.0024-0.0373)\end{array}$ & $<0.0001$ \\
\hline $\begin{array}{l}\text { Disposition } \\
\text { index120 }\end{array}$ & $\begin{array}{c}0.0154 \\
(0.0019-0.0984)\end{array}$ & $\begin{array}{c}0.0250 * \& \\
(0.0062-0.0984)\end{array}$ & $\begin{array}{c}0.0128 \\
(0.0019-0.0283)\end{array}$ & $\begin{array}{c}0.0093 \\
(0.0023-0.0433)\end{array}$ & 0.0006 \\
\hline НОМА В\% & $\begin{array}{c}50.1 \\
(13.4-199.2)\end{array}$ & $\begin{array}{c}78.15^{\#} \\
(35.20-199.2)\end{array}$ & $\begin{array}{c}63.80^{\wedge} \\
(20.40-117.3)\end{array}$ & $\begin{array}{c}33.50 \\
(13.40-81.90)\end{array}$ & 0.0002 \\
\hline
\end{tabular}

\footnotetext{
$\# \mathrm{p}<0.001$ (group 1 vs. group 3); ${ }^{\circ} \mathrm{p}<0.05$ (group 1 vs. group 2 and group 1 vs. group 3); \& $\mathrm{p}<0.01$ (group 1 vs. group 3 ); ${ }^{*} \mathrm{p}<0.01$ (group 1 vs. group 2);^ $\mathrm{p}<0.05$ (group 2 vs. group 3 );
}

group means were analyzed by one-way $\mathrm{AN}$ OVA. All statistical analyses were performed using Excel, GraphPadPrism4 and GraphPadInStat. Statistical significance was set at $\mathrm{p}<0.05$.

\section{Results}

Out of 51 patients who signed the informed consent, two were lost to follow-up, one withdrew consent and for one venous access could not be obtained. Finally, 47 subjects with newly diagnosed diabetes were included in the analysis.

The demographic and metabolic characteristics of the subjects at baseline are presented in Table 1. The mean age of the participants was 55.8 \pm 9.7 years and there was an equal distribution between genders. Fasting blood glucose (mean of two values) at diagnosis ranged from 129 to 521 $\mathrm{mg} / \mathrm{dl}$, while HbA1c varied between $5.5 \%$ and $14 \%$. Sixteen subjects presented typical symptoms of diabetes for a mean duration of $5.5( \pm 2.1)$ months before diagnosis was established and this did not correlate with the degree of hyperglycemia.

Total and early insulin secretion was estimated by using simple indices derived from fasting samples and from the OGTT: the early secretion by the insulinogenic index 30 and dis- position index 30 , while the overall secretion by the insulinogenic index 120 and disposition index120, as well as by HOMA B\% (Table 2). Data is presented for entire group and separately for the three therapeutical groups. At baseline, total $\mathrm{C}$ peptide secretion during the OGTT varied widely $(19.10$ to 1482 $\mathrm{ng} / \mathrm{ml} / 120 \mathrm{~min}$ ) and there were significant differences between the three groups $(\mathrm{p}<0.0001)$ : median AUC was $578.3 \mathrm{ng} / \mathrm{ml} / 120 \mathrm{~min}$ (range: 241.5 $1482 \mathrm{ng} / \mathrm{ml} / 120 \mathrm{~min})$ in group 1, 333.0 $\mathrm{ng} / \mathrm{ml} / 120 \mathrm{~min}$ (range: $19.10-669.0 \mathrm{ng} / \mathrm{ml} / 120 \mathrm{~min}$ ) in group 2 and $193.8 \mathrm{ng} / \mathrm{ml} / 120 \mathrm{~min}$ (range: 49.70 $532.5 \mathrm{ng} / \mathrm{ml} / 120 \mathrm{~min}$ ) in group 3 . The median value of the disposition index30 was 0.0085 (range: 0.0004-0.0416) and of disposition index120 was 0.0154 (range: 0.0019-0.0984). Both indices were significantly different between the three therapeutical groups indicating in fact a decrease with a more severe glycemic decompensation at baseline: in subjects on metformin the disposition index was significantly higher (both for 30 and $120 \mathrm{~min}$ ) than in those that started combined therapy or insulin therapy, but these indices were not significantly different between the later groups.

The incremental $\mathrm{C}$ peptide AUC was mirrored by the AUC for blood glucose concen- 

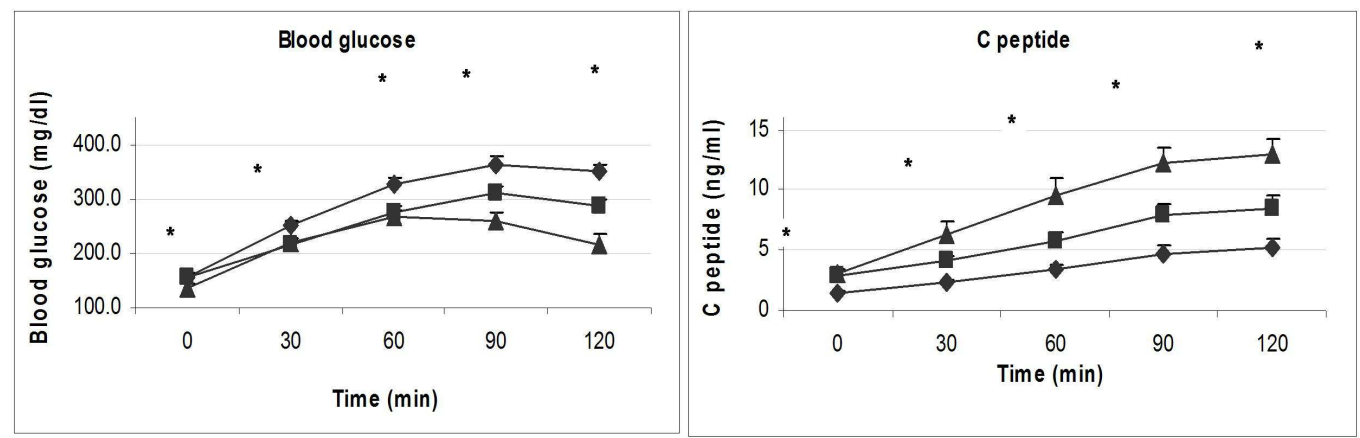

Figure 1. Blood glucose (A) and C peptide (B) levels at baseline. Triangles: metformin treated group; squares: combined treated group; diamonds: insulin treated group; $* \mathrm{p}<0.05$. Data are means $\pm \mathrm{SE}$.
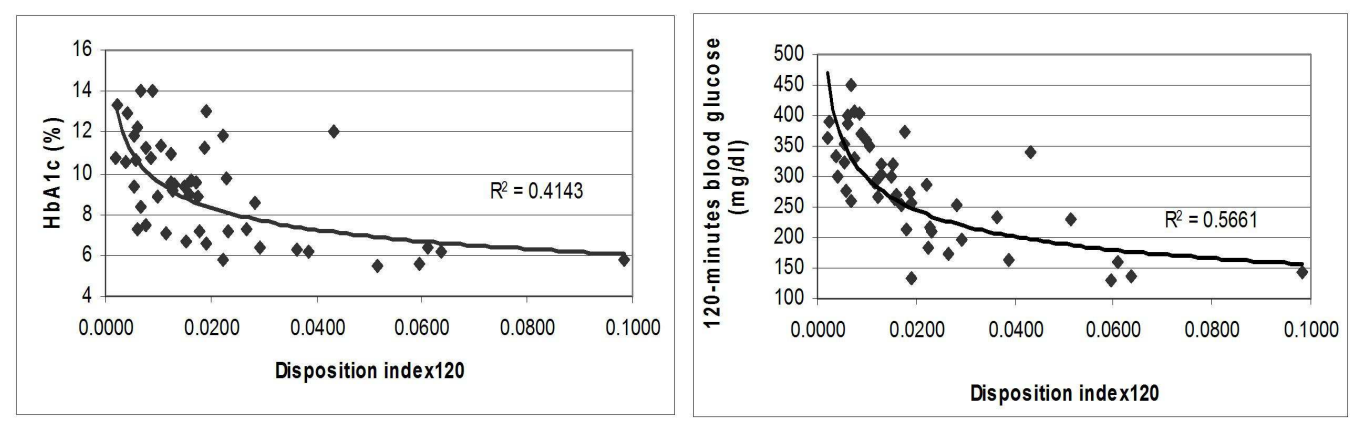

Figure 2. Relationship between disposition index 120 and HbA1c (A) and blood glucose at 120 minutes post-load (B).

trations, that were significantly different in the three groups at baseline $(p<0.0001)$ The time course of glucose response was also different, as the mean time to maximal glucose levels was significantly shorter for group 1 compared with the other two groups $(71.7 \pm 18.2$ min for group 1 vs. $94.6 \pm 11.3 \mathrm{~min}$ for group 2 and $101.3 \pm$ 15.0 min for group 3, p<0.0001) (Figure 1).

In order to identify the markers that are best indicative of beta cell dysfunction at diagnosis, several metabolic and immunologic parameters have been correlated with indices of early and overall insulin secretion. Coefficients of correlation and 95\% CI (confidence interval) for fasting and OGTT-based indices are shown in table 3. For both early and overall beta cell function indices, highly significant negative correlations were found for glycemic markers, mainly $\mathrm{HbAlc}$, blood glucose values at 120 minutes and maximal blood glucose amplitude during the OGTT $(p<0.0001)$. When HbAlc was related to indices of insulin secretion (early and total), the relationship turned out to be non-linear (Figure 2A). A similar relationship was noted for blood glucose levels at 120 post-load (Figure 2B).

When the relationships between beta cell function and $\mathrm{C}$ peptide or proinsulin values were examined, it was demonstrated that the fasting $\mathrm{C}$ peptide positively correlated with the insulinogenic index (30 and 120), but this correlation was lost when the adjustment for insulin resistance was done (disposition indices), while fasting proinsulin did not correlate with either indices. The fasting proinsulin/C peptide ratio was significantly correlated with disposition index only for the early phase insulin secretion (r: -0.3793 ; $95 \%$ CI: -0.6066 to -0.0947 ; p: 0.0085), while for 120 minutes there was a 

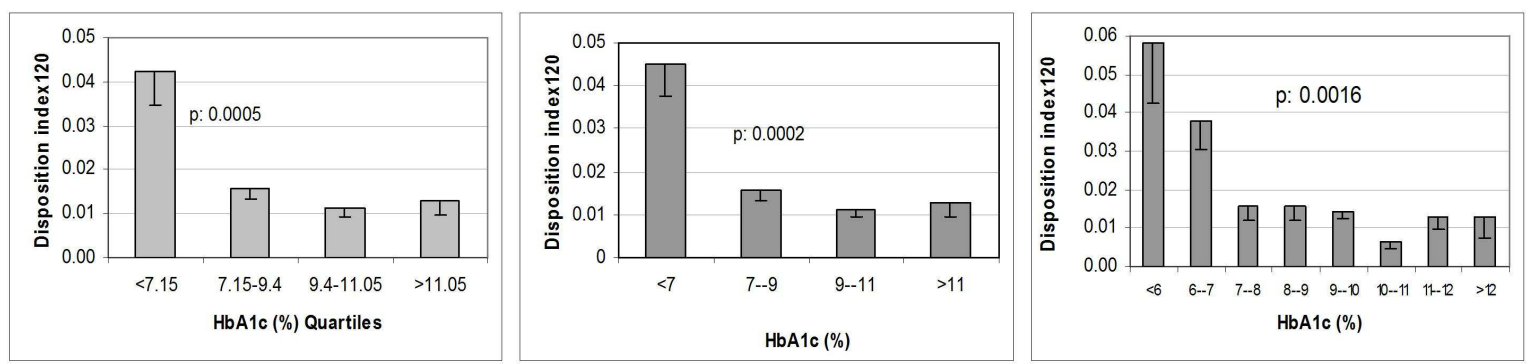

Figure 3. Relationship between disposition index120 and HbA1c quartiles (A) and different HbA1c intervals (B and C). Data are means \pm SE.

negative, non significant correlation (p: 0.0780 ). In contrast, fasting proinsulin was positively correlated with HOMA-IR (Spearman r: 0.5960 ; $95 \%$ CI: 0.3650 to $0.7579 ; \mathrm{p}<0.0001$ ), while fasting $\mathrm{C}$ peptide with body mass index (BMI), a marker of insulin resistance (HOMA-IR could not be used, because it is calculated based on fasting $\mathrm{C}$ peptide values) (Pearson r: $0.4275,95 \%$ CI: 0.1599 to 0.6366 , p: $0.0027)$. C peptide values at 120 minutes displayed a significant positive correlation with both insulinogenic and disposition index (early and overall). Similar to the fasting values, the proinsulin levels at 120 minutes post load were correlated with insulinogenic index 30 and 120, but the correlation was lost when adjustments for insulin resistance were done (disposition index), although for the disposition index 120 the significance level was borderline (p: 0.0552). The proinsulin/C peptide ratio at 120 minutes did not correlate with indices of early insulin secretion, but was negatively correlated with insulinogenic and disposition index 120 (Table 3).

The other serum markers (cytokines, autoantibodies, triglycerides, total cholesterol, HDL cholesterol, LDL cholesterol) showed no association with any indicators of insulin secretion in our study group. BMI was correlated only with insulinogenic indices, but not with disposition index (Table 3).

In order to increase discrimination among degrees of glucose tolerance after the onset of diabetes and because indices of insulin secretion best correlated with glycemic markers, data was divided into quartiles of $\mathrm{HbAlc}$. The quartiles thresholds of $\mathrm{HbAlc}$ for our data were: $7.15 \%$, $9.4 \%$ and $11.05 \%$, respectively. As expected, there was a significant difference between the disposition index quartiles (p: 0.0005), and the first quartile was significantly higher than the third and forth quartiles $(\mathrm{p}<0.01)$ (Figure $3 A)$.

Based on these HbAlc thresholds, slightly different values were chosen $(7 \%, 9 \%$ and $11 \%$ ) in order to improve discrimination between glycemic status groups and to identify patterns that could be more easily generalized (Figure 3B). The analyses indicated significant differences between disposition index30 and 120 , respectively, for $\mathrm{HbA} 1 \mathrm{c}$ groups, and that there was an important decrease of the insulin secretion above $\mathrm{HbA1c}$ value of $7 \%$, which then leveled out. The disposition index120 decreased with $65.38 \%$ in $\mathrm{HbA1c}$ group $7-9 \%$ versus group $<7 \%$, while the disposition index30 decreased with $64.65 \%$.

The data was further divided into each $\%$ of HbA1c: $<6 \%, 6-7 \%, 7-8 \%$ etc (Figure 3C). The total insulin secretion adjusted for insulin resistance decreased with $35.01 \%$ in the 6-7\% group compared to $\mathrm{HbA1c}$ group $<6 \%$, and with other $58.85 \%$ in the $7-8 \%$ group versus $6-7 \%$ group, and thereafter the decrease was not significant. When the third group (7-8\%) was compared to the first one $(<6 \%)$, it turned out that there was a $73.26 \%$ reduction of total insulin secretion. 


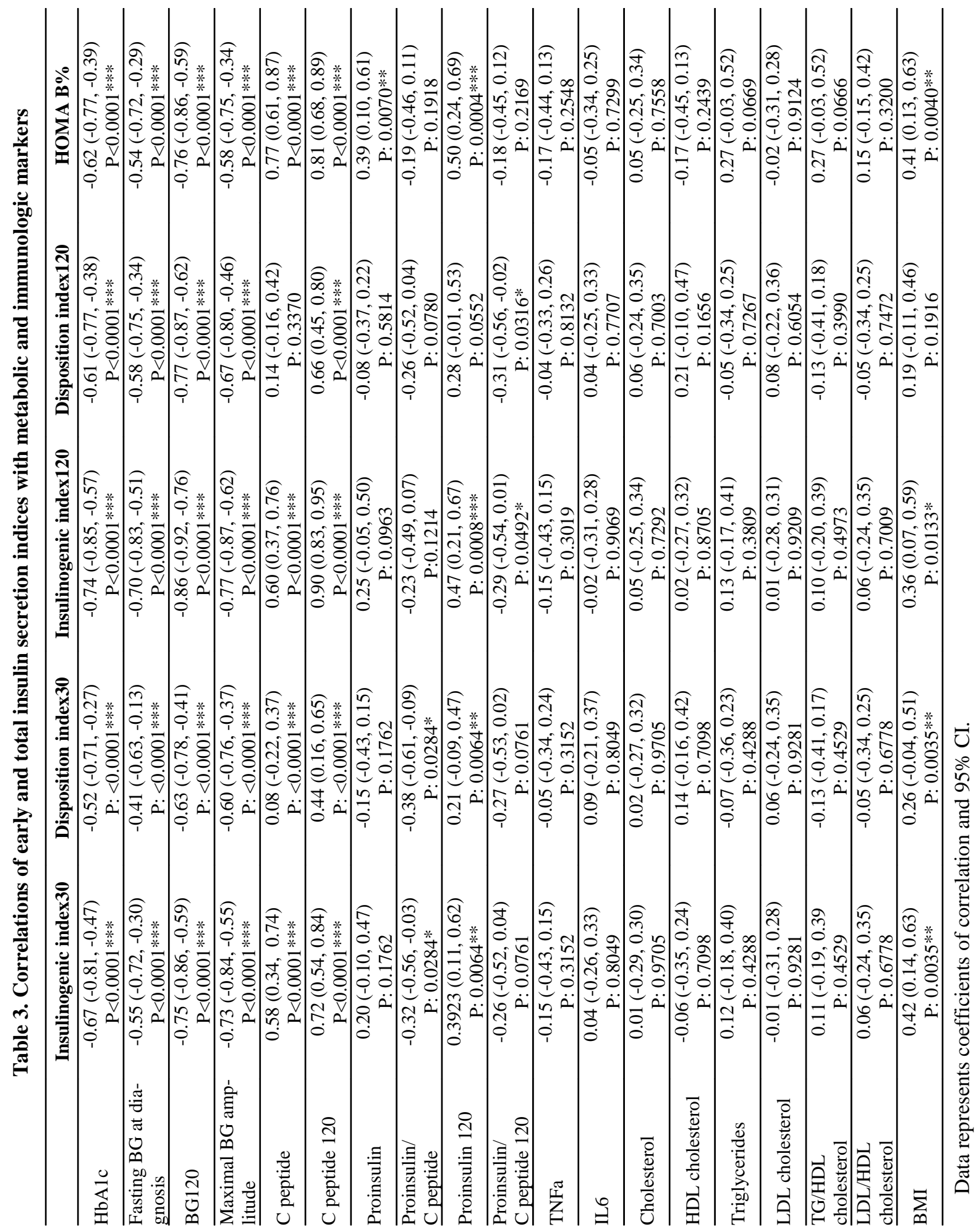



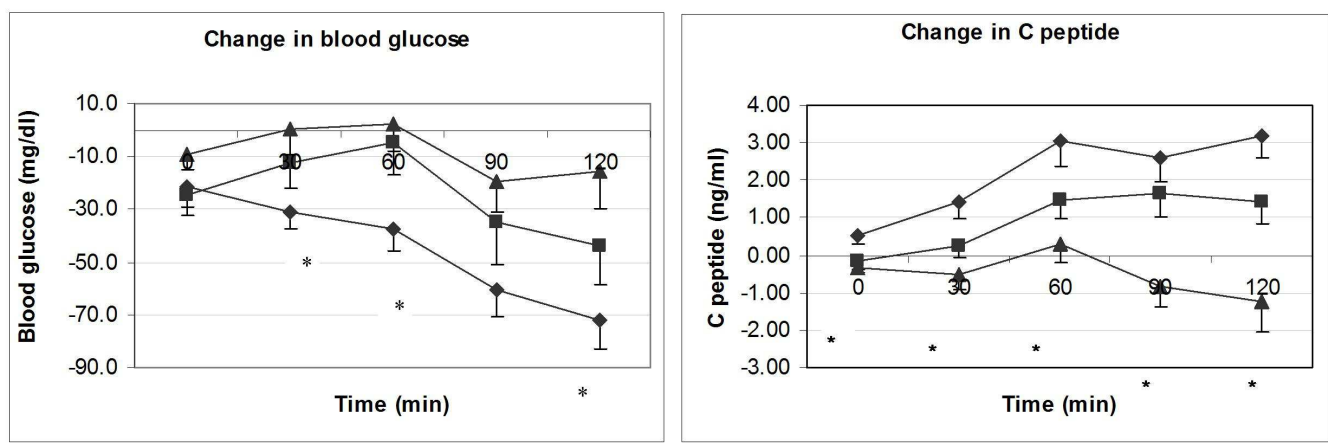

Figure 4. Changes in blood glucose $(A)$ and $C$ peptide $(B)$ concentrations in the three therapeutical groups. Triangles: metformin treated group; squares: combined treated group; diamonds: insulin treated group; $* \mathrm{p}<0.05$. Data are means \pm SE.
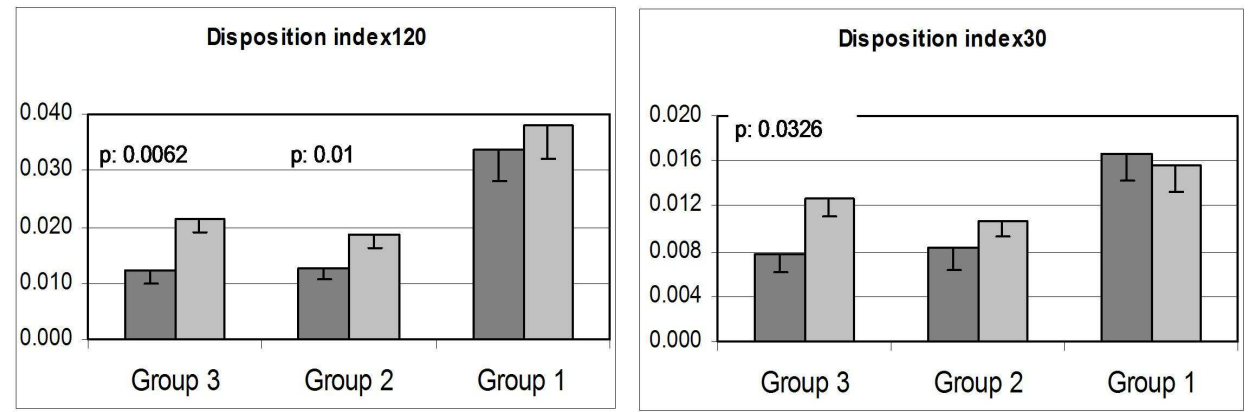

Figure 5. Changes in disposition index120 (A) and disposition index30 (B) with therapy (group 1: metformin treated, group 2: combined therapy, group 3: insulin treated). Light bars: baseline, dark bars: 6 months. Data are means \pm SE.

Similarly, for the early insulin secretion we found a decrease of $74.39 \%$ between $\mathrm{HbAlc}$ group $7-8 \%$ versus $\mathrm{HbA1c}$ group $<6 \%$, with the most important reduction at the threshold of $\mathrm{HbA} 1 \mathrm{c}$ of $7 \%$ (with $-25.8 \%$ in the $6-7 \%$ group versus $<6 \%$ group and with further $-65.48 \%$ in the $7-8 \%$ versus $6-7 \%$ group).

We then evaluated the effect of therapy on insulin secretion after 6 months. The HbAlc significantly decreased at 6 months compared to baseline, in the insulin treated and combination groups $(11.5 \pm 1.6 \%$ to $7.1 \pm 0.9 \%, \mathrm{p}<0.001$ and $9.9 \pm 1.3 \%$ to $7.3 \pm 1.3 \%$, p: 0.003 , respectively), while it did not change significantly in the metformin group $(6.7 \pm 1.0 \%$ to $6.6 \pm 0.7 \%$, p: 0.837$)$.

The time courses of the $\mathrm{C}$ peptide and blood glucose changes in the three therapeutic groups are shown in Figure 4. The total AUC for $C$ peptide increased at 6 months in subjects treated with insulin (with/without metformin) (from $233.41 \pm 164.15 \mathrm{ng} / \mathrm{ml} / 120 \mathrm{~min}$ to 439.91 $\pm 263.26 \mathrm{ng} / \mathrm{ml} / 120 \mathrm{~min}, \mathrm{p}: 0.0005)$ and with combination therapy (from $356.73 \pm 186.68$ $\mathrm{ng} / \mathrm{ml} / 120 \mathrm{~min}$ to $496.64 \pm 283.8 \mathrm{ng} / \mathrm{ml} / 120 \mathrm{~min}$, p: 0.0058), while 30 minutes AUC C peptide improved significantly only in insulin treated group (from $12.29 \pm 8.88 \mathrm{ng} / \mathrm{ml} / 30 \mathrm{~min}$ to 26.18 $\pm 23.7 \mathrm{ng} / \mathrm{ml} / 30 \mathrm{~min}$, p: 0.0017). Similarly, when insulin secretion adjusted to insulin resistance was assessed, insulin therapy and combined therapy groups significantly improved total beta cell function at 6 months (p: 0.0062 and 0.01 , respectively), while the early disposition index was improved only with insulin ther- 

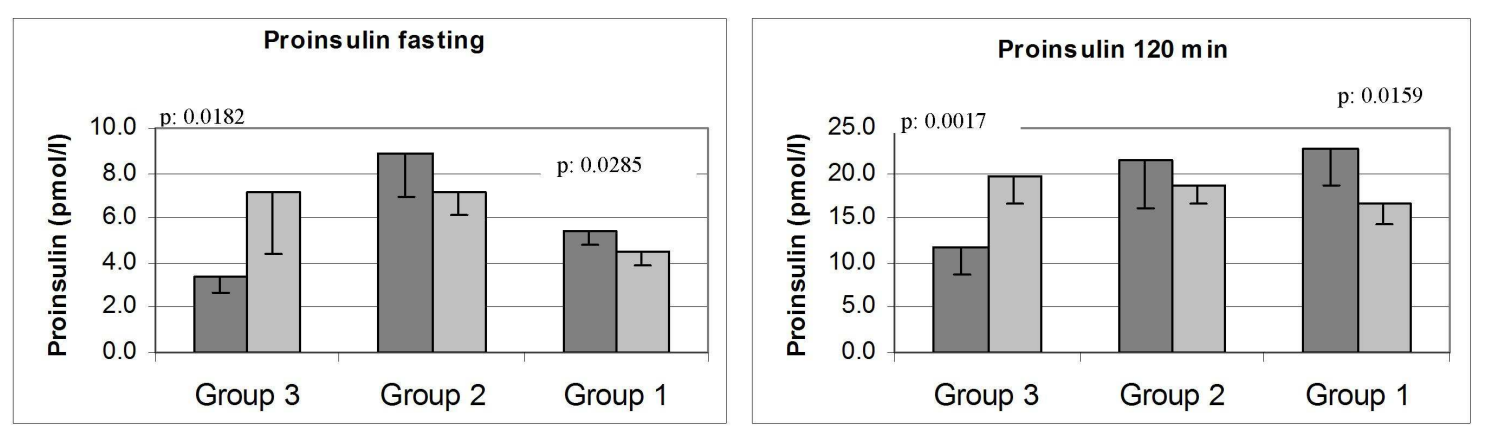

Figure 6. Changes in fasting proinsulin levels $(A)$ and 120-minutes proinsulin levels $(B)$ with therapy (group 1: metformin treated, group 2: combined therapy, group 3: insulin treated). Dark bars: baseline, light bars: 6 months. Data are means \pm SE.

apy (p: 0.0326) (Figure 5B). When the change in total disposition index was plotted against change in HbA1c, a linear relationship was noted (data not shown).

In the insulin therapy group, fasting and 120 minutes post-load proinsulin levels increased at 6 months compared to baseline, while in the metformin treated group a decrease was noted in the same parameters (Figure 6). Fasting proinsulin/C peptide ratio increased from $2.4 \pm 1.76$ $\mathrm{pmol} / \mathrm{l}$ at baseline to $3.24 \pm 3.08 \mathrm{pmol} / \mathrm{l}$ at 6 months (p: 0.0092), while the 120 minutes ratio did not change significantly (p: 0.1941) in subjects treated with insulin. In the metformin group the proinsulin/C peptide ratio at 120 minutes decreased from $1.91 \pm 1.11 \mathrm{pmol} / \mathrm{l}$ at baseline to $1.59 \pm 0.98 \mathrm{pmol} / \mathrm{l}$ at 6 months (p: 0.0423 ), while the fasting ratio did not change. No significant changes were observed in fasting or 120 minutes proinsulin concentrations or proinsulin/C peptide ratios in patients treated with the combination of gliclazide and metformin.

The serum levels of TNF- $\alpha$ did not change significantly at 6 months compared to baseline in the insulin therapy group (10.42 \pm $13.81 \mathrm{pg} / \mathrm{ml}$ vs. $13.18 \pm 10.03 \mathrm{pg} / \mathrm{ml}$, p: 0.1591 ), while in the combination group there was an increase with borderline non-significance $(6.68 \pm 5.86 \mathrm{pg} / \mathrm{ml}$ vs. $10.87 \pm 8.55 \mathrm{pg} / \mathrm{ml}$, p: 0.0546). IL 6 levels presented a decrease with borderline non-significance in the insulin treated group $(1.42 \pm 1.95 \mathrm{pg} / \mathrm{ml}$ vs. $0.64 \pm 1.3$ $\mathrm{pg} / \mathrm{ml}, \mathrm{p}: 0.0537)$, and there was no significant change in the combination group $(0.69 \pm 0.57$ $\mathrm{pg} / \mathrm{ml}$ vs. $0.45 \pm 0.93 \mathrm{pg} / \mathrm{ml}$, p: 0.1230 ).

\section{Discussion}

The current study was designed to assess pancreatic beta cell function by means of OGTT at time of diagnosis in subjects with phenotypic type 2 diabetes and correlate it with various laboratory and clinical parameters. The purpose was to identify simple, accessible markers that best estimate residual beta cell function and that eventually can guide treatment choice.

Subjects with type 2 diabetes are diagnosed at various stages of the disease. In this study the fasting blood glucose and $\mathrm{HbAlc}$ levels at diagnosis varied largely, from mild to severe hyperglycemia and only a third of patients (about half of those with fasting blood glucose over $180 \mathrm{mg} / \mathrm{dl}$ ) presented specific symptoms. This indicates that the disease is heterogeneous, and that at the moment of diagnosis, subjects are at different stages of disease progression characterized by changes in beta cell mass and function (11). This perspective was also confirmed in our research by the fact that the early and total insulin secretion evalu- 
ated during the stimulation test decreased with a more pronounced metabolic decompensation.

Previous studies have also indicated a decrease in glucose stimulated insulin secretion with deterioration of glucose tolerance. Most of these have associated the decrease in beta cell function with a rise in 2-hour blood glucose, but also with an increase in fasting glycemia (1, 12, 13). Moreover, studies reported that incremental AUC for blood glucose values during the OGTT strongly correlated with beta cell function in individuals without diagnosis of diabetes and that it is also a strong predictor for future risk of type 2 diabetes (14). In our study, both early and overall beta cell function measured during the OGTT highly correlated with glycemic markers, mainly HbA1c and blood glucose levels at 120 minutes and the association turned out to be non-linear and negative for both parameters. Therefore, measuring $\mathrm{HbA} 1 \mathrm{c}$ and/or performing an OGTT at the moment of diagnosis is essential for estimating the degree of beta cell function.

When the analysis of data according to HbA1c quartiles was done we found that the level of $7 \%$ discriminated a significant decrease of beta cell function as evaluated by disposition index. This threshold identified a significant reduction of approx. $65 \%$ of beta cell function, both for the first 30 and 120 minutes. Moreover, when data was further divided into subgroups of each percent of HbA1c (<6\%, 6-7\%, 7-8\%, a.s.o), the results was that between HbA1c levels of $6 \%$ and $7 \%$ the insulin secretion decreased with about a third from values obtained at $\mathrm{HbA} 1 \mathrm{c}<6 \%$. There was a further reduction of beta cell function of more than half above HbA1c of $7 \%$, which then leveled out for values of $\mathrm{HbA} 1 \mathrm{c}$ over $8 \%$. Even if the number of subject per group was small, this is a relevant finding, because subjects with $\mathrm{HbA} 1 \mathrm{c}$ values over $6 \%$ already manifest a significant decrease of early and total beta cell function, and the reduction is even more pronounced above $7 \%$. The ADA criteria currently use HbAlc value of $6.5 \%$ for diagnosis of diabetes and define the interval of 5.7-6.5\% as high-risk group (8). In our study, subjects with HbA1c levels between 7 and $8 \%$ (and more) at diagnosis have only about a quarter of the insulin secretion capacity present at HbA1c less than $6 \%$. Therefore the interval of $6 \%$ to $7 \%$ should be carefully re-evaluated because this is when a great part of beta cell function is lost. Thus we argue that the cut point of $\mathrm{HbA} 1 \mathrm{c}$ of $6 \%$ might be a more appropriate threshold for diagnosis of diabetes and even for initiation of therapy. In fact, our results are in accordance with recent findings of Kanat et al. in subjects of Mexican American decent without a previous diagnosis of diabetes, demonstrating that as HbA1c increases $>6 \%$ both insulin sensitivity and beta cell function decrease markedly (3). The authors also advocate that HbA1c level of $6 \%$ is a more adequate threshold for diagnosis of diabetes (3).

Among the other parameters evaluated in this research, only $\mathrm{C}$ peptide and proinsulin seemed to be of relevance. Given the advantage of $\mathrm{C}$ peptide over insulin measurement (the concentrations of the former not being affected by hepatic clearance), and since some of our subjects received insulin therapy for 6 months, we decided to use $\mathrm{C}$ peptide concentrations and proinsulin/C peptide ratios for evaluation of beta cell function. A recent publication evaluating prospective data from a large multi-ethnic adult group without diabetes at baseline included in the Insulin Resistance Atherosclerosis Study (IRAS) concluded that the proinsulin-to-C peptide ratio is a stronger predictor of diabetes than proinsulin-to-insulin ratio and more accurately reflects the degree of disproportional hyperproinsulinemia (15). In our research, fasting $\mathrm{C}$ peptide and proinsulin at baseline turned out to be indicators of insulin resistance, while the ratio of proinsulin to $\mathrm{C}$ peptide was a marker of early beta cell function. This is accordance with findings from other researchers that showed a significant negative correlation between $\mathrm{C}$ peptide quantiles and insulin sensitivity and highly positive correlation with BMI (16). Earlier research found positive correlations between fasting $\mathrm{C}$ peptide and intra-abdominal fat area, an in- 
dicator of insulin resistance (17). Similarly, other authors showed that elevated intact proinsulin levels are a highly specific marker of insulin sensitivity and that it correlates with waist circumference, after adjustment for body fat (18-20). Thus, it can be postulated that hyperproinsulinemia and high fasting $\mathrm{C}$ peptide values are secondary to augmented secretory demand on beta cells induced by insulin resistance and hyperglycemia, although a primary defect in proinsulin processing that occur in type 2 diabetes, possibly aggravated by the increased demand, is also evoked $(21,22)$.

Our results indicated a negative correlation between fasting proinsulin/C peptide ratio and early insulin secretion, while for the total secretion there was only borderline non-significance (p: 0.078), but given the limitations of the study (mainly a relative small number of subjects) a definite conclusion cannot be drawn regarding this aspect. However, the proinsulin/C peptide ratio at 120 minutes after the glucose load correlated well with total insulin secretion. $\mathrm{C}$ peptide levels at 120 minutes were indicative not only of overall, but also for early insulin secretion. Although the correlation of 2-hour C peptide with beta cell function was quite strong and highly significant, it might be argued that it is more difficult to use this parameter in clinical practice, and fasting markers are more preferable. However, the OGTT with two blood draws (fasting and at 2 hours) is already used in practice for diagnosis of diabetes and it might be useful to measure $\mathrm{C}$ peptide concentrations at the same time points with glucose, for better evaluation of beta cell function and insulin sensitivity.

The other parameters that we evaluated (blood lipids, immune markers) did not have a major impact on beta cell function, at least in our study group. Even considering study limitations, in our view the data is indicative of the fact that chronic hyperglycemia has the strongest impact on beta cell function and other factors have a secondary role. Hyperglycemia can therefore be viewed as a cause, a consequence and an indicator of beta cell dysfunction.
The deleterious effects of hyperglycemia on beta cell function are additionally demonstrated by the fact that insulin secretion improves after treatment with exogenous insulin. Our data from treatment-naive patients with newly diagnosed diabetes indicated that insulin therapy (with/out metformin) and the combination of gliclazide with metformin increased total insulin secretion (also adjusted for insulin resistance) during the OGTT at 6 months versus baseline. However, only insulin therapy significantly improved both early and overall beta cell function. These effects might be, at least in part, due to relief of glucotoxicity, given that these two groups of patients had high blood glucose concentrations at diagnosis that significantly decreased at follow up. A number of previous studies demonstrated that shortterm intensive insulin therapy in newly-diagnosed subjects with type 2 diabetes was followed by improvement of glycemic control and insulin secretion, associated with high remission rates (maintenance of normoglycemia after withdrawal of insulin) (23-25). Other reports with different study designs and therapeutical algorithms (e.g. longer duration of insulin therapy, use of premix or basal insulin regimens) have basically indicated the same point: insulin therapy has a beneficial effect on preservation of beta cell secretory function, even in the long term (26-29). Similar to our findings, a recent paper showed that chronic treatment with longacting basal insulin improved both first- and second-phase insulin secretion (evaluated by intravenous glucose tolerance test) in hyperglycemic patients with type 2 diabetes (30). Moreover, recently published data from a large a multicentre randomized clinical trial indicated that insulin therapy initiated in pre-diabetic stage prevented/delayed the onset of disease (31). The mechanisms through which insulin exerts beneficial effects on pancreatic beta cell function are not fully elucidated. Some of the proposed ones are amelioration of glucotoxicity, the "beta cell rest" that alleviates the demand placed 
on pancreatic beta cells, attenuation of endoplasmic reticulum-crowding with improvement in proinsulin maturation and insulin secretion, and anti-inflammatory effects known to positively influence beta cell growth and survival $(32,33)$.

Some authors suggested that therapy with sulphonylurea is deleterious to beta cells through increased secretory demand leading to cell exhaustion/desensitization, possibly acceleration of oxidative stress and apoptosis (34, 35). These may eventually cause a progressive reduction of insulin production capacity, deterioration of glycemic control over time and treatment failure $(28,36)$. However, more recent work has shown that there are substantial differences between different sulphonylureas, and that gliclazide has in fact anti-oxidant properties, does not change gene expression or cell survival, but rather protects beta cells from apoptosis and thus may preserve functional beta cell mass $(37,38)$. This may explain our findings showing that after 6 months of therapy with gliclazide, total insulin secretion during the OGTT increased. Another argument in favor of this would be the following: part of the improvement in beta cell function is related to development of normoglycemia and reduction of glucotoxicity; however since similar effects on glucose were described with glibenclamide without clear improvement in beta cell function, we may assume that gliclazide might have particular effects (39). Metformin on the other hand, did not change beta cell function. Although it is assumed that due to its anti-inflammatory properties and alleviation of insulin resistance metformin improves beta cell function, and even though some in vitro evidence suggest that it may prevent beta cell apoptosis, clinical data failed to show beta cell preservation and improvement in insulin secretion with metformin therapy $(10,40,41)$. This is relevant for practice because current therapeutical algorithms advocate metformin as first-line therapy (42). However, in view of these data it might be wise to reconsider these recommendations in the sense that therapeutical agents with potential to improve beta cell function and/or mass should be considered at least in non-obese subjects with reduced beta cell functional capacity at onset.

Previous studies with DPP4 inhibitors showed that the positive effects on beta cell function were associated with a decrease in proinsulin and increase in insulin in response to glucose (43). Surprisingly, our data indicated that fasting and stimulated proinsulin concentration increased with insulin therapy and decreased with metformin. These changes might be due to similar alterations of insulin resistance, since proinsulin correlated with insulin resistance. A surprising finding in our study was that even if fasting $\mathrm{C}$ peptide levels increased with insulin therapy, the fasting proinsulin/C peptide ratio also increased at 6 months, implying changes in cellular hormone content with a disproportionate increase in proinsulin levels. Some studies indicated that exogenous insulin exposure enhances glucose-stimulated insulin secretion and that hyperinsulinemia enhances $\mathrm{C}$ peptide clearance $(44,45)$. A possible explanation for the increased proinsulin/C peptide ratio in fasting (and not stimulated) state after insulin therapy could be due to the recovery of some (pre-apoptotic) functionally heterogeneous beta cells, with increased content of immature granules (with higher proinsulin concentrations), but this theory remains to be confirmed.

Our study had some limitations: the relatively small number of subjects and the relatively short duration of the study (6 months). In addition, subjects that received insulin had worse metabolic control at baseline than those receiving combined therapy, so a direct comparison between the two therapeutical algorithms cannot be made, because the patients were probably in different stages of disease. Interestingly, in these circumstances, insulin therapy still demonstrated best effects on beta cell function. This could be due to: the very beneficial effects of insulin on beta cell rest and function or may be a result of acute correction of severe glucotoxicity, resulting in recovery of beta cell function. Because the insulin regimens 
were not homogenous, however, we cannot draw any conclusion regarding the effect of a certain insulin regimen on beta cell function. It remains to be investigated which insulin regimen is optimal for beta cell protection (if there are any differences) and also what duration of therapy is needed in order to obtain the best effects on beta cell function.

\section{Conclusions}

In summary we have shown that beta cell function at diagnosis of type 2 diabetes correlated well with markers of glycemic control, mainly HbA1c and 2-hour blood glucose during the OGTT. The level of $7 \%$ discriminated a significant decrease of approximately $65 \%$ of beta cell function as evaluated by disposition index, both for the first 30 and for 120 minutes. Fasting proinsulin and $\mathrm{C}$ peptide were indices of insulin resistance, while 2-hour $\mathrm{C}$ peptide and proinsulin/C peptide ratio were indicators of beta cell function. Therefore we suggest that the determination of $\mathrm{HbAlc}$ at first visit and even performance of an OGTT with concomitant measurement of blood glucose and $\mathrm{C}$ peptide (fasting and 2-hour) is of major importance for a correct evaluation of beta cell functional capacity at diagnosis of diabetes. We have also demonstrated that insulin therapy started at onset improved both early and total insulin secretion at 6 months.

\footnotetext{
Abbreviations

OGTT - oral glucose tolerance test

ADA - American Diabetes Association

HbA1c - glycated hemoglobin

BG - blood glucose

AUC - area under the curve

$\mathrm{CV}$ - coefficient of variation

TNF- $\alpha$ - tumor necrosis factor $\alpha$

IL-6 - interleukin 6

GAD - glutamic acid decarboxylase

IA2 - insulinoma antigen 2

HOMA - Homeostasis Model Assessment

BMI - body mass index
}

\section{Acknowledgements}

The proinsulin, TNF- $\alpha$, IL- 6 , antiGAD and antiIA2 antibodies kits were provided by the University of Medicine and Pharmacy Târgu Mureş. The authors thank Ionela ColojiSângeorzan RN, Mihaela Muscă RN, Ionela Hanas RN and Maria Pop RN for their help with the OGTT.

\section{References}

1. Bi Y, Zhu D, Jing Y, Hu Y, Feng W, Shen S, et al. Decreased beta cell function and insulin sensitivity contributed to increasing fasting glucose in Chinese. Acta Diabetol 2012; 49 Suppl 1: S51-8.

2. Ferrannini E, Gastaldelli A, Miyazaki Y, Matsuda M, Mari A, DeFronzo RA. Beta-Cell function in subjects spanning the range from normal glucose tolerance to overt diabetes: a new analysis. J Clin Endocrinol Metab 2005; 90: 493-500.

3. Kanat M, Winnier D, Norton L, Arar N, Jenkinson C, DeFronzo RA, et al. The relationship between $\{$ beta $\}$-cell function and glycated hemoglobin: results from the veterans administration genetic epidemiology study. Diabetes Care 2011; 34: 1006-10.

4. Pfützner A, Weber MM, Forst T. A biomarker concept for assessment of insulin resistance, beta-cell function and chronic systemic inflammation in type 2 diabetes mellitus. Clin Lab 2008; 54: 485-90.

5. Muniyappa R, Lee S, Chen H, Quon MJ. Current approaches for assessing insulin sensitivity and resistance in vivo: advantages, limitations, and appropriate usage. Am J Physiol Endocrinol Metab 2008; 294: E15-26.

6. Bacha F, Gungor N, Arslanian SA. Measures of betacell function during the oral glucose tolerance test, liquid mixed-meal test, and hyperglycemic clamp test. J Pediatr 2008; 152: 618-21.

7. Tripathy D, Almgren P, Tuomi T, Groop L. Contribution of insulin-stimulated glucose uptake and basal hepatic insulin sensitivity to surrogate measures of insulin sensitivity. Diabetes Care 2004; 27: 2204-10.

8. American Diabetes Association. Diagnosis and classification of diabetes mellitus. Diabetes Care 2010; 33 Suppl 1: S62-9.

9. Mari A, Pacini G. Methods for the Assessment of $\beta$ cell Function in vivo; in "Clinical Diabetes and Research: Methods and Techniques" Editor Michael Roden; John Wiley \& Sons Ltd., 2007, pg 7-27.

10. Defronzo RA. Banting Lecture. From the triumvirate to the ominous octet: a new paradigm for the treatment of type 2 diabetes mellitus. Diabetes 2009; 58: 773-95.

11. Weir GC, Bonner-Weir S. Five stages of evolving 
beta-cell dysfunction during progression to diabetes. Diabetes 2004; 53 Suppl 3: S16-21.

12. Bi Y, Zeng L, Zhu D, Yan J, Zhang Y, Tong G, et al. Association of $\beta$-cell function and insulin sensitivity with fasting and 2-h plasma glucose in a large Chinese population. Diabetes Obes Metab 2012; 14: 174-80.

13. Abdul-Ghani MA, Matsuda M, Jani R, Jenkinson CP, Coletta DK, Kaku K, et al. The relationship between fasting hyperglycemia and insulin secretion in subjects with normal or impaired glucose tolerance. Am J Physiol Endocrinol Metab 2008; 295: E401-6.

14. Abdul-Ghani MA, DeFronzo RA. Plasma glucose concentration and prediction of future risk of type 2 diabetes. Diabetes Care 2009; 32 Suppl 2: S194-8.

15. Loopstra-Masters RC, Haffner SM, Lorenzo C, Wagenknecht LE, Hanley AJ. Proinsulin-to-C-peptide ratio versus proinsulin-to-insulin ratio in the prediction of incident diabetes: the Insulin Resistance Atherosclerosis Study (IRAS). Diabetologia 2011; 54: 3047-54.

16. Banu S, Jabir NR, Manjunath CN, Shakil S, Kamal MA.C-peptide and its correlation to parameters of insulin resistance in the metabolic syndrome. CNS Neurol Disord Drug Targets 2011; 10: 921-7.

17. Bergstrom RW, Newell-Morris LL, Leonetti DL, Shuman WP, Wahl PW, Fujimoto WY. Association of elevated fasting C-peptide level and increased intra-abdominal fat distribution with development of NIDDM in Japanese-American men. Diabetes 1990; 39: 104-11.

18. Pfützner A, Kunt T, Hohberg C, Mondok A, Pahler $\mathrm{S}$, Konrad T, et al. Fasting intact proinsulin is a highly specific predictor of insulin resistance in type 2 diabetes. Diabetes Care 2004; 27: 682-7.

19. Hanley AJ, McKeown-Eyssen G, Harris SB, Hegele RA, Wolever TM, Kwan J, et al. Cross-sectional and prospective associations between abdominal adiposity and proinsulin concentration. J Clin Endocrinol Metab 2002; 87: 77-83.

20. Pfützner A, Forst T. Elevated intact proinsulin levels are indicative of Beta-cell dysfunction, insulin resistance, and cardiovascular risk: impact of the antidiabetic agent pioglitazone. J Diabetes Sci Technol. 2011 May;5(3):78493.

21. Røder ME, Kahn SE. Suppression of Beta-cell secretion by somatostatin does not fully reverse the disproportionate proinsulinemia of type 2 diabetes. Diabetes 2004; 53 Suppl 3: S22-5.

22. Grill V, Dinesen B, Carlsson S, Efendic S, Pedersen $\mathrm{O}$, Ostenson CG. Hyperproinsulinemia and proinsulin-to-insulin ratios in Swedish middle-aged men: association with glycemia and insulin resistance but not with family history of diabetes. Am J Epidemiol 2002; 155: 834-41.

23. Ilkova H, Glaser B, Tunçkale A, Bagriaçik N, Cerasi E. Induction of long-term glycemic control in newly diagnosed type 2 diabetic patients by transient intensive insulin treatment. Diabetes Care 1997; 20: 1353-6.
24. Ryan EA, Imes S, Wallace C. Short-term intensive insulin therapy in newly diagnosed type 2 diabetes. Diabetes Care 2004; 27: 1028-32.

25. Weng J, Li Y, Xu W, Shi L, Zhang Q, Zhu D, et al. Effect of intensive insulin therapy on beta-cell function and glycaemic control in patients with newly diagnosed type 2 diabetes: a multicentre randomised parallel-group trial. Lancet 2008; 371: 1753-60.

26. Bhattacharya S, Ammini AC, Jyotsna V, Gupta N, Dwivedi S. Recovery of $\beta$-cell functions with low-dose insulin therapy: study in newly diagnosed type 2 diabetes mellitus patients. Diabetes Technol Ther 2011; 13: 461-5. 27. Chen HS, Wu TE, Jap TS, Hsiao LC, Lee SH, Lin HD. Beneficial effects of insulin on glycemic control and beta-cell function in newly diagnosed type 2 diabetes with severe hyperglycemia after short-term intensive insulin therapy. Diabetes Care 2008; 31: 1927-32.

28. Alvarsson M, Berntorp K, Fernqvist-Forbes E, Lager I, Steen L, Orn T, et al. Effects of insulin versus sulphonylurea on beta-cell secretion in recently diagnosed type 2 diabetes patients: a 6-year follow-up study. Rev Diabet Stud 2010; 7: 225-32.

29. Harrison LB, Adams-Huet B, Raskin P, Lingvay I. $\beta$ cell function preservation after 3.5 years of intensive diabetes therapy. Diabetes Care 2012; 35: 1406-12.

30. Pennartz C, Schenker N, Menge BA, Schmidt WE, Nauck MA, Meier JJ. Chronic reduction of fasting glycemia with insulin glargine improves first- and secondphase insulin secretion in patients with type 2 diabetes. Diabetes Care 2011; 34: 2048-53.

31. ORIGIN Trial Investigators, Gerstein HC, Bosch J, Dagenais GR, Díaz R, Jung H, Maggioni AP, et al. Basal insulin and cardiovascular and other outcomes in dysglycemia. N Engl J Med 2012; 367: 319-28.

32. Brown RJ, Rother KI. Effects of beta-cell rest on beta-cell function: a review of clinical and preclinical data. Pediatr Diabetes 2008; 9: 14-22.

33. Absood A, Gandomani B, Zaki A, Nasta V, Michail A, Habib PM, et al. Insulin therapy for pre-hyperglycemic beta-cell endoplasmic reticulum crowding. PLoS One 2013; 8: e54351.

34. Maedler K, Carr RD, Bosco D, Zuellig RA, Berney T, DonathMY. Sulfonylurea induced beta-cell apoptosis in cultured human islets. J Clin Endocrinol Metab 2005; 90 : 501-6.

35. Irwin N, McKinney JM, Bailey CJ, Flatt PR, McClenaghan NH. Effects of metformin on BRIN-BD11 betacell insulin secretory desensitization induced by prolonged exposure to sulphonylureas. Diabetes Obes Metab 2010; 12: 1066-71.

36. Shin MS, Yu JH, Jung CH, Hwang JY, Lee WJ, Kim MS, et al. The duration of sulfonylurea treatment is associated with $\beta$-cell dysfunction in patients with type 2 diabetes mellitus. Diabetes Technol Ther 2012; 14: 1033-42. 37. Del Guerra S, Grupillo M, Masini M, Lupi R, Bugliani M, Torri S, et al. Gliclazide protects human islet 
beta-cells from apoptosis induced by intermittent high glucose. Diabetes Metab Res Rev 2007; 23: 234-8.

38. Magnusson NE, Dyrskjøt L, Grimm D, Wehland M, Pietsch J, Rungby J. Gene networks modified by sulphonylureas in beta cells: a pathway-based analysis of insulin secretion and cell death. Basic Clin Pharmacol Toxicol 2012; 111: 254-61.

39. Alvarsson M, Sundkvist G, Lager I, Henricsson M, Berntorp K, Fernqvist-Forbes E, et al. Beneficial effects of insulin versus sulphonylurea on insulin secretion and metabolic control in recently diagnosed type 2 diabetic patients. Diabetes Care 2003; 26: 2231-7.

40. Lablanche S, Cottet-Rousselle C, Lamarche F, Benhamou PY, Halimi S, Leverve X, et al. Protection of pancreatic INS-1 $\beta$-cells from glucose- and fructose-induced cell death by inhibiting mitochondrial permeability transition with cyclosporin A or metformin. Cell Death Dis 2011; 2:e134.

41. DeFronzo RA, Abdul-Ghani MA. Preservation of $\beta$ cell function: the key to diabetes prevention. J Clin Endocrinol Metab 2011; 96: 2354-66.

42. Inzucchi SE, Bergenstal RM, Buse JB, Diamant M,
Ferrannini E, Nauck M, et al. Management of hyperglycaemia in type 2 diabetes: a patient-centered approach. Position statement of the American Diabetes Association (ADA) and the European Association for the Study of Diabetes (EASD). Diabetologia 2012; 55: 1577-96.

43. Forst T, Dworak M, Berndt-Zipfel C, Löffler A, Klamp I, Mitry M, et al. Effect of vildagliptin compared to glimepiride on postprandial proinsulin processing in the $\beta$ cell of patients with type 2 diabetes mellitus. Diabetes Obes Metab. 2013 Jun;15(6):576-9.

44. Lopez X, Cypess A, Manning R, O'Shea S, Kulkarni $\mathrm{RN}$, Goldfine AB. Exogenous insulin enhances glucose-stimulated insulin response in healthy humans independent of changes in free fatty acids. J Clin Endocrinol Metab 2011; 96: 3811-21.

45. Halperin F, Lopez X, Manning R, Kahn CR, Kulkarni RN, Goldfine AB. Insulin augmentation of glucose-stimulated insulin secretion is impaired in insulin-resistant humans. Diabetes 2012; 61: 301-9. 